\title{
Constraints Analysis of Litopenaeus vannamei Culture in Prakasam District, Andhra Pradesh, India
}

\author{
Prathibha Bharathi Chittem*, Sumanth Kumar Kunda \\ Department of Zoology and Aquaculture, Acharya Nagarjuna University, Nagarjuna Nagar, India
}

*Corresponding Author: Prathibha Bharathi Chittem, Department of Zoology and Aquaculture, Acharya Nagarjuna University, Nagarjuna Nagar, India

\begin{abstract}
Litopenaeus vannamei (shrimp) farming is playing a pivotal role in the socio-economic development of India. India is exporting 4.4 lakh tones of shrimp products (2016-17) of which vannamei share is 3.30 lakh tonnes. The Andhra Pradesh state is the largest vannamei producer amongst the shrimp farming states of India contributing 2.31 lakh tonnes (70\% of total Indian exports). A study was undertaken during 2014-15 in Prakasam district of Andhra Pradesh, to analyze the constraints prevailed in L.vannamei culture. The Prakasam district has 3 revenue divisions and 56 Mandals (Taluka's) with 2,273.39 ha brackish water area is under shrimp culture. The study area was selected purposively and the respondents were identified using simple random technique. The sample size for the current investigation was 60. The study was conducted based on personal interview schedule aided with well structured and pre-tested questionnaire consisting of 11 items of constraints such as seed, feed, diseases, management aspects, inputs, harvest, labour related, extension activities, infrastructure, marketing and miscellaneous constraints. Garrett's ranking technique was employed for allotment of ranking to the various constraints. The data was analyzed using frequency and percentages. The results showed that out of the total farmer's surveyed, input constraint (rank1) was opted as the major constraint, followed by other constraints such as lack of marketing (rank-2), infrastructure constraint (rank-3), Seed constraint (rank-4), management constraint (rank-5), Miscellaneous constraint (rank-6), disease constraint (rank-7), Feed constraint (rank-8), harvest constraints (rank-9), extension constraint (rank-10) and labour constraint (rank-11). The results were reflecting the existing scenario of L.vannamei culture in the study area. Irrespective of the ranking of the various constraints, majority of the constraints were the reasons behind the setback of vannamei crop failure. The study conclude that the regulating agencies such as MPEDA of GOI to take appropriate remedial measures to combat the identified constraints of the present study.
\end{abstract}

Keywords: Litopenaeus vannamei, Garrett ranking, Better Management Practices (BMP's) and Constraints.

\section{INTRODUCTION}

Aquaculture is the fastest- growing form of food production in the world and shrimp dominates the aquaculture production by value. Shrimp aquaculture is the fastest growing food area and its economic importance is increasing concurrently. It is an important sector in the majority of the countries of the world from the viewpoint of income and employment generation. From the year 2010 to 2015, shrimp export volume increased at a compound annual growth rate of $15.8 \%$. Since 2009-10, vannamei (Litopenaeus vannamei) production has shown consistent growth and reached 4.06 lakh MT (metric tones) during 2015-16, increasing the overall shrimp production to about 5 lakh MT. In India, the state of Andhra Pradesh stands first both in coastal and inland aquaculture production.

The Andhra Pradesh state is contributing half of the total shrimp production of India. It has a coast line of $974 \mathrm{KM}$ and about 175,000 Ha of area is under shrimp culture. Penaeus monodon was the leading shrimp culture during 1990's. Due to the outbreak of WSSV and other associated problems, the Litopenaeus vannamei (Pacific white legged shrimp), an exotic species was introduced during 2009 as an alternative species to P.monodon. Litopenaeus vannamei (shrimp) farming playing an vital role in the socio-economic development of India. Aquaculture technology is continuously getting improved to cope up with the emerging scenario. Better Management Practices (BMP's) is one such technology adopted by organized farming community for better yields and sustainable environment. In short, the implementation of the BMPs has provided benefits to the farmers, environment, and society (Mohan et al. 2008). The culture vannamei had increased rapidly in all the maritime states of 
India. The Andhra Pradesh state has become hub of shrimp aquaculture and it has been cultured on commercial scale in 9 coastal districts. India is exporting 4.4 lakh tones of shrimp products (2016-17) of which vannamei share is 3.30 lakh tonnes. The Andhra Pradesh state is the largest vannamei producer amongst the shrimp farming states of India contributing 2.31 lakh tonnes (70\% of total Indian exports). In recent times, the vannamei culture also receiving severe setback due to several reasons and lead to crop losses.

In view of this background, the present study was aimed to analyse various constraints of shrimp aquaculture in Prakasham district of Andhra Pradesh state and an attempt was made to find necessary site-specific remedial measures to the identified constraints.

\section{Materials AND Methods}

The present study was conducted in Prakasham district of Andhra Pradesh during the second crop (September / October) of 2014-15. It was selected purposively so as to get hands-on information about diversification of various existing problems of vannamei growers.

\subsection{Locale of the Study}

The Prakasam district (Fig.1) lies between $15^{\circ}-30^{\prime}$ of the Northern latitude and $80^{\circ}-60^{\prime}$ of the Eastern longitude, average rainfall is $1753 \mathrm{~mm}$. It is located on the west coast of Bay of Bengal and is bounded by Guntur district on the north, Kurnool district on the west, Kadapa and Nellore districts on the south. It is the $3^{\text {rd }}$ largest district in the state with an area of $17,626 \mathrm{~km}^{2}(6,805 \mathrm{sq} \mathrm{mi})$ and had a population of 3,392,764 as per 2011 census of India (Anon, 2017). It has 3 revenue divisions with 56 mandals/taluks. The district has $102 \mathrm{~km}$ long coastline and $3859 \mathrm{sq} . \mathrm{km}$ area of continental shelf. The $102 \mathrm{~km}$ long coastline offers very good scope for brackish water shrimp culture and the district had attracted major corporate bodies besides many small farmers towards this activity. Brackish water shrimp farming was taken up in 9 mandals (talukas) involving 1293 farmers from 35 villages in the district covering 2273.39 ha at present. All farmers have got the licenses from the Coastal Aquaculture Authority, Govt.of India.

\subsection{Research Design}

The present study was conducted during the year 2014-15 in the district of Prakasam district of Andhra Pradesh State, India. Ex-post-facto research design was used in the present investigation. According to Robinson (1976), ex-post-facto design is any systematic empirical inquiry in which the independent variables have not been directly manipulated because they have already occurred or because they are not inherently manipulable Both purposive and simple sampling technique were employed for the present study.

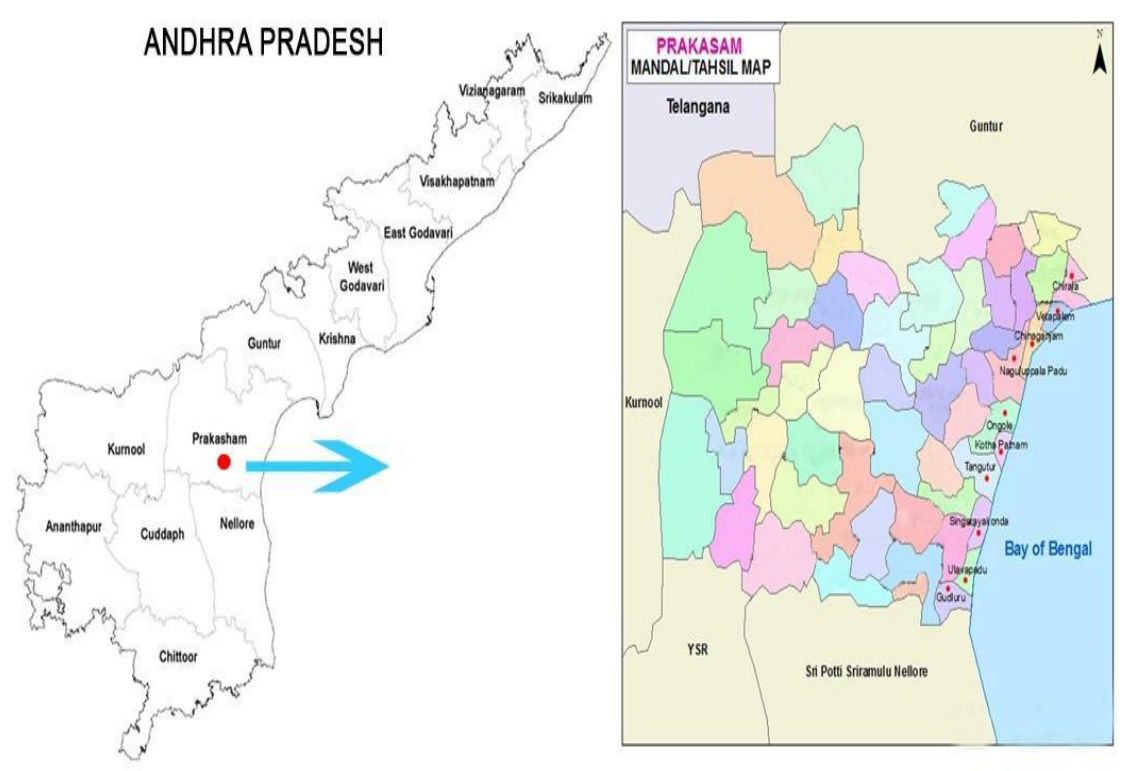

Fig1. Location of Prakasham District of Andhra Pradesh state, India (Source: Anon, 2017) 


\subsection{Population and Sample}

The population for the study covers the small-scale ( $<2$ ha area ) farmers of L.vannamei culture, where majority of the shrimp cultivators are depending on shrimp aquaculture as their main livelihood, L.vannamei farming activity was large and reported high production in the Prakasam district The sampling district was selected purposively and revenue based on the number of shrimp farmers, farming area, production and diversity of problems. Interview schedule with a well structured questionnaire was used as a tool for the present study. A set of 11 items out of 50 was incorporated in the questionnaire. A. pilot study was also conducted prior to the present study.

\subsection{Selection of Revenue Division - First stage selection}

The Prakasham district has a total of 3 revenue divisions viz. Kandukur, Markapur and Ongole. As the Ongole division has coastline with abundant brackish water area is under shrimp culture and a majority of small -scale growers are prevalent, it was identified as the sampling division for the present study.

\subsection{Identification of Mandals (taluks) - Second Stage of Selection}

The Ongole division has 20 Mandals (taluks) and information about authorized (obtained approval for farming from CAA, Govt.of India) vannamei farmers in each Mandal was obtained from the Department of Fisheries, A.P. Accordingly Mandals were identified based on the availability of number of farmers. For the present study, 3 Mandals viz. Tangutur, Kothapatnam and China Ganjam were selected purposively based on the history of problems and crop failures.

\subsection{Selection of Respondents - Third Stage of Selection}

The technique of proportionate and simple random sampling was adopted to select the required number of respondents for vannamei farming practices in each mandal. A sample size of 60 respondents was selected out of 3 Mandals and 20 respondents were selected from each Mandal (Table.1).

Table1. Selections of Respondents

$(\mathrm{n}=60)$

\begin{tabular}{|c|c|c|c|c|}
\hline \multirow{4}{*}{\begin{tabular}{|c|}
$\begin{array}{c}\text { Name of the } \\
\text { Mandal }\end{array}$ \\
Tangutur \\
\end{tabular}} & \multirow{2}{*}{$\begin{array}{c}\begin{array}{c}\text { Total No of } \\
\text { identified } \\
\text { respondents }\end{array} \\
473\end{array}$} & \multirow{2}{*}{$\begin{array}{c}\begin{array}{c}\text { No.of } \\
\text { respondents } \\
\text { selected }\end{array} \\
20\end{array}$} & \multicolumn{2}{|c|}{ No. of respondents in each selected village } \\
\hline & & & Ananthavaram & 10 \\
\hline & & & Velagapudi & 5 \\
\hline & & & Tallapalem & 5 \\
\hline \multirow[t]{3}{*}{ Kothapatnam } & \multirow[t]{3}{*}{265} & \multirow[t]{3}{*}{20} & Mandanur & 8 \\
\hline & & & Ethamukkala & 7 \\
\hline & & & Kothapatnam & 5 \\
\hline \multirow[t]{3}{*}{ Chinnaganjam } & \multirow[t]{3}{*}{405} & \multirow[t]{3}{*}{20} & Peddaganjam & 9 \\
\hline & & & Chinnaganjam & 6 \\
\hline & & & Munnamvaripalem & 5 \\
\hline
\end{tabular}

\subsection{Statistical Tools Used in the Study}

The collected data was tabulated, scored, and analyzed using frequency, percentage and Garrett (1969) ranking technique using the following formula.

Garrett's ranking technique was used. As per this method, respondents have been asked to assign the rank for all factors and the outcome of such ranking has been converted into score value with the help of the following formula:

$$
\text { Percent position }=\frac{100(\mathrm{Rij}-0.5)}{\mathrm{Nj}}
$$

Where

Rij = Rank given for the ith variable by jth respondents

$\mathrm{Nj}=$ Number of variable ranked by jth respondents 
With the help of Garrett's Table, the percent position estimated is converted into scores. Then for each factor, the scores of each individual are added and then total value of scores and mean values of score is calculated. The factors having highest mean value is considered to be the most important factor.

\section{RESULTS AND DISCUSSION}

The results (Tab.2) showed that 11 constraints are the major constraints which are playing significant role in the success of vannamei culture. All the identified 11 constrains had been influenced by another sub-component of the farming practices. All these constraints were analysed using frequency and percentage and ranking was given accordingly.

Table2. Constraints of vannamei shrimp farmers in Prakasham district $\quad(n=60)$

\begin{tabular}{|c|c|c|}
\hline Constraint & Frequency & Percentage \\
\hline \multicolumn{3}{|c|}{ I. Seed constraints } \\
\hline Non availability of quality seed & 18 & 30.00 \\
\hline High cost of the seed & 39 & 65.00 \\
\hline Inadequate supply of hatchery seeds in the required time & 36 & 60.00 \\
\hline Mixed seed or differential size of the seed from hatcheries & 25 & 41.66 \\
\hline Heavy mortality of hatchery seeds due to poor quality & 22 & 36.66 \\
\hline Lack of adequate No.of near by hatchery units & 14 & 23.00 \\
\hline \multicolumn{3}{|l|}{ II. Feed Constraints } \\
\hline High cost of feed & 55 & 91.66 \\
\hline Low quality of feed & 48 & 80.00 \\
\hline Lack of feed processing units ( Feed mills) & 51 & 85.00 \\
\hline Aflotoxins in feed & 03 & 05.00 \\
\hline \multicolumn{3}{|c|}{ III. Disease Constraints } \\
\hline WSSV & 20 & 33.33 \\
\hline Any other & 24 & 40.00 \\
\hline \multicolumn{3}{|c|}{ IV. Management Constraints } \\
\hline Non-availability of land near to sea shore & 04 & 06.66 \\
\hline $\begin{array}{l}\text { Water management } \\
\text { Absence of proper inlet (Feeding) and outlet (Drainage) }\end{array}$ & 04 & 06.66 \\
\hline Problem of bad count & 30 & 50.00 \\
\hline Problem of theft & 04 & 06.66 \\
\hline Problem of birds & 06 & 10.00 \\
\hline Quarantine standards & 35 & 58.33 \\
\hline Knowledge about services of MPEDA/CAA & 34 & 56.66 \\
\hline Information on export oriented standards & 08 & 13.00 \\
\hline \multicolumn{3}{|c|}{ V Input constraints } \\
\hline Quality manure not available & 06 & 10.00 \\
\hline $\begin{array}{l}\text { Lack of Prophylactic treatment } \\
\text { Problems related to Medicines }\end{array}$ & 02 & 03.33 \\
\hline Manure and fertilizers not available in local markets & 34 & 56.66 \\
\hline Problems related to fuel & 48 & 80.00 \\
\hline \multicolumn{3}{|c|}{ VI Labour Constraints } \\
\hline Inadequacy of the family labour & 41 & 68.33 \\
\hline Scarcity of the hired labour & 26 & 43.33 \\
\hline Demand of higher wages during peak season & 30 & 50.00 \\
\hline Employment of unskilled and untrained labour & 22 & 36.66 \\
\hline \multicolumn{3}{|c|}{ VII Harvest constraints } \\
\hline Time of harvest & 05 & 08.33 \\
\hline Lack of labour & 30 & 50.00 \\
\hline \multicolumn{3}{|c|}{ VIII. Extension Constraints } \\
\hline Lack of proper extension network & 05 & 08.33 \\
\hline Lack of regular training programmes & 05 & 08.33 \\
\hline Lack of information on technology & 16 & 26.66 \\
\hline $\begin{array}{l}\text { Lack of private consultants } \\
\text { Approach to extension agency / Distance }\end{array}$ & 05 & 08.33 \\
\hline Demonstrations Published literature Subsidies (Inputs) & 03 & 05.00 \\
\hline
\end{tabular}




\begin{tabular}{|c|c|c|}
\hline \multicolumn{3}{|c|}{ IX Infrastructure Constraints } \\
\hline Lack of roads & 05 & 08.33 \\
\hline Lack of good transport & 07 & 11.66 \\
\hline Lack of communication facilities & 02 & 03.33 \\
\hline Lack of power & 52 & 86.66 \\
\hline $\begin{array}{l}\text { Lack of drinking water supply } \\
\text { Salination of drinking water wells due to heavy withdrawal }\end{array}$ & 11 & 18.33 \\
\hline Deterioration of soil quality of pond & 05 & 08.33 \\
\hline \multicolumn{3}{|c|}{ X. Marketing Constraints } \\
\hline Price fluctuations of inputs & 42 & 70.00 \\
\hline Lack of storage facilities & 51 & 85.00 \\
\hline Selling at pond site & 11 & 18.33 \\
\hline Distance from the market & 06 & 10.00 \\
\hline $\begin{array}{l}\text { Lack of ice factories and plastic factories for proper storage of } \\
\text { produce }\end{array}$ & 45 & 75.00 \\
\hline Lack of information on price & 48 & 80.00 \\
\hline High commission charges & 14 & 23.33 \\
\hline Lack of Govt. support & 51 & 85.00 \\
\hline Constraints faced due to Govt. policies & 47 & 78.00 \\
\hline \multicolumn{3}{|l|}{ XI Miscellaneous Constraints } \\
\hline Lack of facilities to test the soil quality & 09 & 15.00 \\
\hline Lack of facilities to test the salinity of the water & 10 & 16.66 \\
\hline Lack of knowledge on tidal fluctuations & 28 & 47.00 \\
\hline Lack of availability of experienced engineers & 18 & 30.00 \\
\hline Lack of insurance policy & 38 & 63.33 \\
\hline Lack of Post harvest knowledge & 07 & 11.66 \\
\hline Weed fishes & 06 & 10.00 \\
\hline Floods \&Drought & 03 & 05.00 \\
\hline Pouching & 01 & 01.66 \\
\hline
\end{tabular}

\subsection{Seed Constraints}

The constraint analysis (Tab.2) of seed showed that majority (65\%) of the respondents facing the constraints of high cost of seed data followed by inadequate supply of required number of hatchery seed $(60 \%)$ within stipulated time. It is also interesting to note that $41.66 \%$ of respondents reported mixed seed or differential size of the seed and few others (36.66 \%) informed that, high mortality of hatchery seed due to poor quality. It is clear that seed is playing success of any culture and stocking of a quality seed will improve the survival rate and also reduce the cost of shrimp production. It is necessary to establish good number hatchery units to the nearby shrimp farming sites. The results are agreeing with the studies of Mohamed et al. (2013), koteswari et al. (2014) and Tejavath Jagadeesh (2015). Srinivas D. and Ch. Venkatrayalu (2016) reveled that Shrimp farming is highly resilient in West Godavari. The lack of availability of quality seed is the major problem for sustainability of the shrimp farming. Disease outbreaks also appeared to be the major threat to shrimp farming.

\subsection{Feed Constraints}

Vannamei feed is the important constraint of shrimp growers of the present study area. Majority (91.66 \%) of respondents reported high cost of feed followed by lack of local feed processing units/Feed mills $(85 \%)$ It was also observed that $80 \%$ of respondents reported poor quality of feed and a very few $(5 \%)$ reported problems of aflotoxins in preserved feed. The present study emphasizes the importance of supply of low priced high quality shrimp feed with long shelf life. It is also necessary to improve the feed storage facilities at shrimp farms such as erecting cold storages at shrimp farms. The results are agreeing with the studies of Mohamed et al. (2013), koteswari et al. (2014) and Tejavath Jagadeesh (2015).

\subsection{Management Constraints}

The results pertaining to the management constraints showed that $58.33 \%$ of respondents attributed to hygienic/bio-secure/ quarantine standards and another $56.66 \%$ of respondents reported ignorance of services of govt. organizations of MPEDA/CAA. The study also found that problems of harvesting marketable count size $(50 \%)$, non-availability of latest information on export standards (13\%), and few $(10 \%)$ reported menace of birds and $6.66 \%$ of respondents reported non-availability of land near 
to sea shore and lack of prophylactic treatment $(03.33 \%)$ was also another reason for the disease prevalence. It is clear evidence that Good Management Practices (GMP's/BMP's) are important in order to yield more amount of marketable size counts as well good quality final product. The study also found the importance of outreach programmes to enable the shrimp grower informed about the advanced methods of vannamei farming. The results are agreeing with the studies of Mohamed et al. (2013), koteswari et al. (2014) and Tejavath Jagadeesh (2015).

\subsection{Disease Constraints}

Prevalence of disease outbreaks in vannamei culture is receiving serious attention in recent times and resulting in crop failures. Majority of the respondents (40\%) of the surveyed experiencing other than WSSV diseases (33.33\%) such as Vibrio sp., white gut, white fecal matter, loose shell etc. The reasons behind the prevalence of diseases other than viral might be poor water quality management, high stocking densities and poor maintenance of BMP's at Shrimp farming facilities. The results are agreeing with the studies of Mohamed et al. (2013), koteswari et al. (2014) and Tejavath Jagadeesh (2015). Jitendrakumar et al. (2016) reported that Disease is the major limiting factor faced by the shrimp farmers and it has become the most burning and threatening issue for shrimp farming communities.

\subsection{Input Constraints}

The vannamei culture is facing serious concern over the increase of input cost/operating cost. The present study had found that increment of fuel cost was the major concern $(80 \%)$ and $56.66 \%$ of respondents reported the scarcity of manure and fertilizers in local markets. Other input related constraints include non-availability of quality manure $(10.00 \%)$ and. During the study it was observed (66.66\%) that inorganic fertilizers were not playing any role in supplying adequate amounts of N, P\& K. It might be due to the companies that they were supplying the inorganic fertilizers. The Govt.of A.P has to make stringent vigilance to verify the labeling of the products of particular companies and verify the actual availability. The results are agreeing with the studies of Mohamed et al. (2013), koteswari et al. (2014) and Tejavath Jagadeesh (2015).

\subsection{Labour Constraints}

The vannamei culture in the present study area had been facing sever constraint about the nonavailability of skilled man power $(36.66 \%)$ and scarcity of required number of hired labour $(43.33 \%)$ during important operations such as stocking, harvesting, mannuring etc.. The biggest constraint $(50 \%)$ of the vannamei culture is demand of higher wages during peak season. The existing shrimp growers were also suffering from inadequacy of the family labour (68.33\%) for their day today activities. The present study had reconfirmed the earlier studies of demand of higher wages and nonavailability of skilled man power. These problems have to be checked by fixing standard prices to the skilled workers/certified workers and appropriate policy has to be prepared by the Govt. Agencies for hiring and wage fixation for the labour in order utilize their services in the vannamei culture facilities. The results are agreeing with the studies of Mohamed et al. (2013), koteswari et al. (2014) and Tejavath Jagadeesh (2015).

\subsection{Marketing Constraints}

In recent times shrimp culture is facing setback due to fluctuation of market prices even though good market is available for good count at global level. The present study also revealed that majority (85 $\%)$ reported lack of Govt. support, lack of ice factories \& storage facilities $(75 \%)$ and $80.00 \%$ of respondents reported lack of information on actual market price where as $78 \%$ respondents attributed to Govt. policies for these constraints. $70 \%$ of respondents reported fluctuations of prices. The fluctuations of shrimp prices and supply of adequate information to shrimp growers at regular intervals by the Govt., is the need of the hour so as to minimize the crop losses. The results are agreeing with the studies of Mohamed et al. (2013), koteswari et al. (2014) and Tejavath Jagadeesh (2015). Koteswari N.et al., (2014) reported that all farmers were producing tonnes of shrimp but there is price fluctuation in the market for the produce which affects their income.

\subsection{Infrastructure Constraints}

The present study analysed the constraints of infrastructure an allied facilities. The results showed that lack of power (86.66\%), lack of roads (8.33\%), lack of transport (11.66\%), lack of adequate drinking 
water faculties (18.33\%) and communication of facilities (3.33\%). The intensity and seriousness of these constraints varied from system to system. These constraint analyses emphasize the importance of site selection criteria to be implemented prior to design of shrimp culture system. Appropriate facilities as mentioned above to be incorporated at reasonable price. Care to be taken inorder to minimize the operational cost of production of vannamei culture. The results are agreeing with the studies of Mohamed et al. (2013), koteswari et al. (2014) and Tejavath Jagadeesh (2015).

\subsection{Miscellaneous \& Others}

The present study had shown that lack of crop insurance was the major constraint for majority $(63.33 \%)$ growers and lack of updated scientific information on vannamei culture (26.66\%) was also another constraint reported by the shrimp growers. The Govt. has to make appropriate crop insurance policies to vannamei culture in the similar lines of agriculture and allied sectors. The results are agreeing with the studies of Mohamed et al. (2013), koteswari et al. (2014) and Tejavath Jagadeesh (2015). Kumaran et al. (2003), and Vadher et al. (2014), shrimp farming was successfully practiced in Andhra Pradesh and Gujarat, although with some constraints. Shrimp aquaculture has contributed significantly in employment generation and infrastructure development of the coastal community and overall development of coastal areas.

\subsection{Ranking of Constraints in L.vannamei Culture}

The data were analyzed using 'Garrett (1969) method of ranking' for all the listed constraints and depicted in Table and depicted in Table 3. The results showed that out of the total farmer's surveyed, input constraint (rank-1) was opted as the major constraint, followed by other constraints such as lack of marketing (rank-2), infrastructure constraint (rank-3), constraint (rank-4), management constraint (rank-5), Miscellaneous constraint (rank-6), disease constraint (rank-7), feed constraint (rank-8), harvest constraints (ranking-9), extension constraint (rank-10) and labour constraint (rank-11).

The ranking of constraints could be utilized for prioritization of constraints in order to make immediate steps on priority basis to address the specific constraint. Even though 11 ranks were opted for each constraints, but all the constraints were playing equal importance in most of the vannamei farms in the study area as the majority of the farmers were experiencing the either of these constraints irrespective of their rank. The results clearly indicated that shrimp farmers are still experiencing the problems of diseases which fetched them severe economic losses. The increase of wages of labour used in the shrimp farming operations and fluctuations of shrimp prices were also the major hurdles perceived by the shrimp growers in the study area. It might be the similar situation prevailed in all the shrimp growing places of rest of the state of Andhra Pradesh.

Table3. Garret's ranks and scores on Constraints encountered by shrimp farmers in BMP's of L.vannamei practices

\begin{tabular}{|c|l|c|c|}
\hline S.NO & Constraints & \multicolumn{1}{|l|}{ Score } & \multicolumn{1}{l|}{ Rank } \\
\hline 1 & Input constraint & 59.31 & I \\
\hline 2 & Marketing constraint & 56.66 & II \\
\hline 3 & Infrastructure constraint & 55.81 & III \\
\hline 4 & Seed constraint & 52.33 & IV \\
\hline 5 & Management constraint & 52.26 & V \\
\hline 6 & Miscellaneous constraint & 51.11 & VI \\
\hline 7 & Diseases constraint & 48.64 & VII \\
\hline 8 & Feed constraint & 46.74 & VIII \\
\hline 9 & Harvest constraint & 44.21 & IX \\
\hline 10 & Extension constraint & 43.93 & X \\
\hline 11 & Labour constraint & 40.01 & XI \\
\hline
\end{tabular}

\section{CONCLUSION}

The present study conclude that vannamei culture even though it was stated with high expectations compared to tiger shrimp, but in recent time it is also receiving severe setbacks due to several constraints and fetching heavier economic losses. The need of the hour is to address all the identified/analyzed constraints with more pragmatic approach and immediate preventive measures to be taken to sustain the vannamei culture in all shrimp farming states in general and Andhra Pradesh state in particular as the later is contributing $70 \%$ of the total Indian shrimp production. The 
constraints such as non-availability of quality seed and feed, high cost of seed and feed, very low support price fixed by the Govt., lack of market facilities, lack of labour, high cost of labor, \& higher input cost are to be addressed with appropriate existing measures which includes adoption Better Management Practices (BMP's) and HACCP principles at vannamei culture facilities in order to produce zero defect shrimp products.

\section{REFERENCES}

[1] Anon, 2017. Prakasham district. https://en.wikipedia.org/wiki/Prakasam_district, accessed online on dated 24.08.2017

[2] Jitendrakumar T. Tandel, Kirtankumar V. Tandel, Gauravkumar M. Tandel \& Patel M. R. 2016. A Socioeconomic survey of shrimp aquaculture practices in Valsad district, Gujarat, India. International journal of research in applied, natural and social sciences. vol. 4, issue 9, sep 2016, 93-98.

[3] Koteswari, N., Sheela Immanuel., Leo Cyril, A.R., Viswanatha, B.S., 2014. Impact of aqua socities on shrimp farming in Andhra Pradesh, India. Fishery Technology 51, 130-135.

[4] Kumaran M, Ravichandran P, Gupta BP, Nagavel A. 2003. Shrimp farming practices and its socioeconomic consequences in East Godavari district, Andhra Pradesh, India- A case study. Aquaculture Asia; $8(3): 48-52$.

[5] Mohan, C.V., M.J. Phillips, B.V. Bhat, N.R. Umesh, and P.A. Padiyar. 2008. Farm level plans/husbandry measures, changing trends in managing aquatic animal disease emergencies: Tools for preparedness and response. OIE Scientific and Technical Review 27(1).

[6] Mohamed E. Megahed, Samir Ghoneim, Gaber Desouky, Ashraf EL-Dakar. 2013. Major Constraints Facing Development of Marine Shrimp Farming in Egypt. Journal of the Arabian Aquaculture Society. Vol. 8 No 2.

[7] Robinson P W 1976 Fundamentals of experimental psychology a comparative approach. Prentice Hall Insecticides, Englewood Cliffs, New Jersey 64.

[8] Srinivas D. and Ch. Venkatrayalu (2016). Studies on present problems and prospects of shrimp farming in West Godavari district of Andhra Pradesh, India. Advances in Applied Science Research, 7(2):49-54.

[9] Tejavath Jagadeesh. 2015. An Economic analysis of shrimp farming practices in Prakasam district, Andhra pradesh. Thesis.

[10] Vadher K. H. and Kapila Manoj. 2014. Study on socio-economic profile of shrimp farmers of Gujarat State, India International Journal of Fisheries and Aquatic Studies; 2(2): 202-205

Citation: Prathibha Bharathi Chittem \& Sumanth Kumar Kunda, "Constraints Analysis of Litopenaeus vannamei Culture in Prakasam District, Andhra Pradesh, India", International Journal of Research Studies in Biosciences (IJRSB), vol. 5, no. 10, pp. 10-17, 2017. http://dx.doi.org/10.20431/2349-0365.0510003

Copyright: () 2017 Authors. This is an open-access article distributed under the terms of the Creative Commons Attribution License, which permits unrestricted use, distribution, and reproduction in any medium, provided the original author and source are credited. 